\title{
Radiographic abnormalities in carcinoma of the lung as related to histological cell type
}

\author{
R. B. B Y R D, D. T. CARR, W. E. M I L L E R, \\ W. S. PA Y NE, A N L . B. WOOLNER \\ From the Sections of Medicine, Roentgenology, Surgery, and Surgical Pathology, Mayo Clinic and \\ Mayo Foundation, and the Mayo Graduate School of Medicine (University of Minnesota), Rochester, \\ Minnesota
}

\begin{abstract}
A detailed study was made of the chest radiographs of 600 patients with bronchogenic carcinoma who had had thoracotomy or intensive radiotherapy. Tumours of the various histological cell types tended to present with different radiographic patterns. Squamous-cell carcinoma was most often characterized by bronchial obstruction, often in association with a hilar mass. Squamous-cell lesions also were far more likely to show cavitation than were lesions of the other cell types. Small-cell carcinoma had a higher percentage of hilar masses than did other tumours but showed less tendency than did squamous-cell carcinoma to produce obstruction in association with the hilar mass. Adenocarcinoma most often presented as a peripheral mass as did large-cell carcinoma.
\end{abstract}

A number of studies have been done to establish the frequency of the various radiographic abnormalities associated with bronchogenic carcinoma, according to the individual cell types (Byrd, Miller, Carr, Payne, and Woolner, 1968a, b, c ; Lehar, Carr, Miller, Payne, and Woolner, 1967 ; Selby, Luomanen, and Sherman, 1963). However, no attempt has been made in any of these studies to compare in detail the differences in the radiographic patterns among tumours having various cell types. Liebow (1955) has approached this problem from the pathological standpoint, describing the chest radiograph as one would expect to see it on the basis of the gross pathological appearance and biological behaviour of each cell type of lung cancer.

We thought it would be of value to approach the problem from the appearance of the chest radiograph at the time of the initial diagnosis, determining what significant differences in the radiographic abnormalities might be present at that time. It was with this goal in mind that we reviewed our radiographic material from previous studies of individual cell types and made the present study.

\section{MATERIALS AND METHODS}

At the Mayo Clinic, bronchogenic carcinoma is classified into four histological cell types: squamous-cell carcinoma, small-cell carcinoma, adenocarcinoma, and large-cell undifferentiated carcinoma. In a previous study, the histological material from all patients with primary cancer of the lung undergoing thoracotomy from 1954 through 1957 had been reviewed (Galofré, Payne, Woolner, Clagett, and Gage, 1964). Pre-operative stereoscopic radiographs of the chest were available, from this group of cases, for 263 cases of squamous-cell carcinoma, 126 of adenocarcinoma, and 97 of large-cell carcinoma. When a similar study of small-cell carcinoma was contemplated at a later date the chest radiographs prior to 1957 were no longer available. Therefore, the case histories and histological material of all patients with small-cell carcinoma, who were seen from 1958 through 1965 at this institution, were reviewed. Preoperative or pre-radiotherapy films were available in 114 cases of small-cell carcinoma, in which the patients either underwent exploratory thoracotomy or were subjected to definitive radiotherapy during this time. Patients receiving intensive radiation therapy were included, since radiation therapy rather than resection is now frequently employed at this institution in cases of small-cell carcinoma, even when the tumour is technically resectable.

In some cases additional radiographs were available for review; these included lateral views, tomograms, and lateral decubitus views. In those cases in which serial films were made during the course of the disease, the earliest film that had been obtained was used.

The radiographs in this study were reviewed and classified in terms of the abnormalities listed in Table I.

By studying radiographs of patients whose diseases 


\section{T A B L E I}

CLASSIFICATION OF RADIOGRAPHIC ABNORMALITIES ASSOCIATED WITH BRONCHOGENIC CARCINOMA

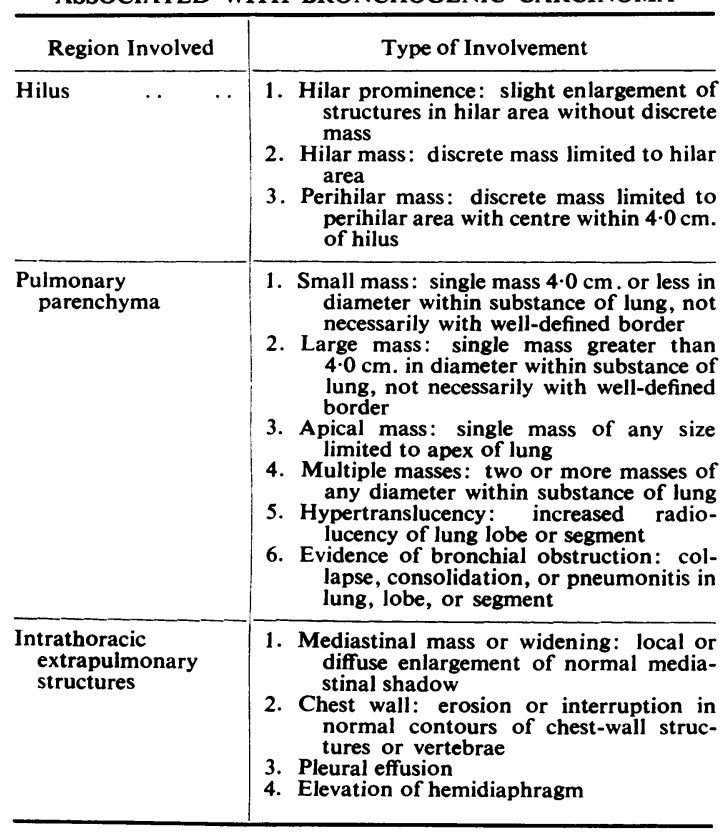

T A B L E I I

FEATURES OF CASES USED IN RADIOGRAPHIC STUDY OF BRONCHOGENIC CARCINOMA

\begin{tabular}{|c|c|c|c|c|}
\hline & \multicolumn{4}{|c|}{ Type of Tumour } \\
\hline & $\begin{array}{l}\text { Squamous- } \\
\text { cell } \\
\text { Carcinoma } \\
(263 \text { cases })\end{array}$ & $\begin{array}{c}\text { Adeno- } \\
\text { carcinoma } \\
\text { (126 cases) }\end{array}$ & $\mid \begin{array}{c}\text { Small- } \\
\text { cell } \\
\text { Carcinoma } \\
(114 \text { cases })\end{array}$ & $\begin{array}{c}\text { Large- } \\
\text { cell } \\
\text { Carcinoma } \\
\text { (97 cases) }\end{array}$ \\
\hline \multirow{3}{*}{ 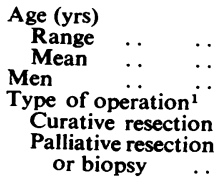 } & $\begin{array}{c}38 \text { to } 79 \\
61 \\
251\end{array}$ & $\begin{array}{c}27 \text { to } 78 \\
57 \\
74\end{array}$ & $\begin{array}{c}42 \text { to } 80 \\
59 \\
105\end{array}$ & $\begin{array}{c}39 \text { to } 79 \\
57 \\
88\end{array}$ \\
\hline & 191 & 82 & 40 & 53 \\
\hline & 72 & 44 & 41 & 44 \\
\hline
\end{tabular}

1 Thirty-three of the patients with small-cell carcinoma had radiation therapy only.

were sufficiently limited to warrant surgical intervention or-in the case of small-cell carcinomadefinitive radiotherapy, we thought that a more accurate differentiation of the radiographic abnormalities would be obtained than if radiographs made during all stages of the disease were used.

\section{RESULTS}

The age range, mean age, sex, and type of operation in the four groups of cases are shown in Table II.

The radiographic abnormalities seen in association with tumours of the various cell types are shown in Table III. Single and multiple abnor malities are differentiated. In no case was hyperlucency present.

Eight patients having squamous-cell carcinomå and one having adenocarcinoma had negative chest radiographs. These included pre-operative films taken the week before operation. In thesè nine cases, bronchoscopy established the diagnosit after the patients had presented with symptoms suggesting lung cancer. None of the patients with small-cell or large-cell carcinoma had negative chest films.

Cavitation in the peripheral and apical masses was evident on the radiographs of 18 of $82 \mathrm{w}$ patients with squamous-cell carcinoma. This type of change was evident on only four radiographs of the 63 patients having large-cell carcinom sD $^{2}$ and on three of those of the 94 having adeno $\frac{\text { Dे }}{\mathbb{D}}$ carcinoma, in which there were peripheral masses

\section{COMMENT}

A mass or prominence in or about the hilus was found to be rather characteristic of the radio. graphic pattern of small-cell carcinoma, occurring in 89 cases $(78 \%)$. In $14(16 \%)$ of these 89 cases the hilar mass probably represented a metastasis as there was an associated peripheral parenchymag tumour. It has been pointed out in pathologica studies that hilar nodes in small-cell carcinom tend to be involved early and massively when the primary lesion is in the parenchyma (Liebow 1955). Hilar or perihilar masses were seen much less frequently with the tumours of other celb types (Table III).

A peripheral mass on the chest radiograph was found to occur most often in association witk. adenocarcinoma, being present in $72 \%$ of the cases. Of patients with large-cell tumours, $63 \%$ had peripheral masses. In contrast, peripherab masses were much less frequently seen in cases of squamous-cell and small-cell carcinoma, occurring in $31 \%$ and $32 \%$, respectively. The high percent age of this abnormality in association with adeno. carcinoma and large-cell carcinoma gives furthen support to the thesis that the majority of largef cell carcinomata are poorly differentiated adeno
carcinomata.

The size of the peripheral masses, as measured on the chest radiographs, varied significantlye according to the histological cell type: $60 \%$ of the peripheral lesions associated with squamous cell carcinoma and $66 \%$ of those with large-celए carcinoma were larger than $4.0 \mathrm{~cm}$. in diameter $\frac{\rho}{\mathbb{D}}$ whereas only $36 \%$ of those with adenocarcinoma and $25 \%$ of those with small-cell carcinoma were 
T A B L E I I I

ABNORMAL RADIOGRAPHIC PATTERNS IN 600 CASES OF CARCINOMA OF THE LUNG AS RELATED TO HISTOLOGICAL

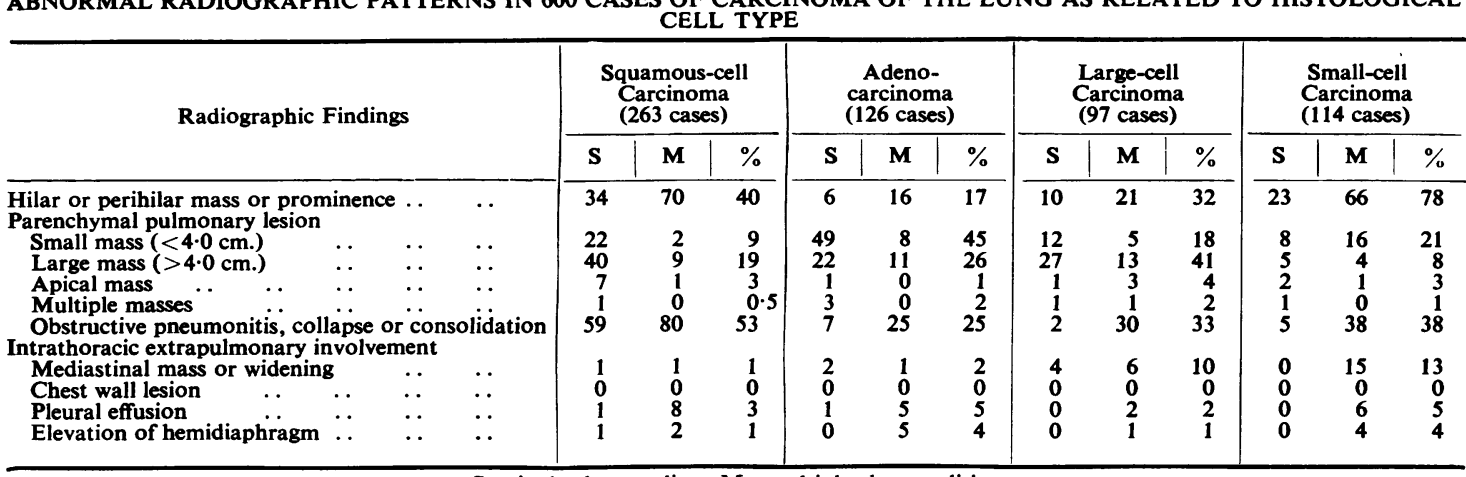

$\mathbf{S}=$ single abnormality; $\mathbf{M}=$ multiple abnormalities.

of this size. Patients with small-cell carcinoma had the smallest peripheral masses, three having tumours only $1.0 \mathrm{~cm}$. in diameter. The largest tumour in the series was a squamous-cell carcinoma $13.0 \mathrm{om}$. in diameter.

Cavitation of peripheral masses occurred in $22 \%$ of the cases of squamous-cell carcinoma, in $6 \%$ of those of large-cell carcinoma, and in $2 \%$ of those of adenocarcinoma. None of the smallcell carcinomata had recognizable cavitation. Strang and Simpson (1953), in a study of 1,930 cases of lung cancer, found radiographic evidence of cavitation in $3.6 \%$, and 36 of the 44 tumours showing cavitation proved to be squamous-cell carcinoma.

If the peripheral tumours occurring in the apex are considered as a separate group, there appears to be no significant tendency for one cell type to predominate.

Evidence of bronchial obstruction, as manifested by obstructive pneumonitis, loss of lung volume, or consolidation, was particularly frequent in association with squamous-cell carcinoma, occurring in $53 \%$ of the cases. Pathological studies have also shown this histological cell type to produce most frequently bronchial obstruction (Lindskog, Liebow, and Glenn, 1962). Other lesions had lower percentages of radiographic evidence of obstruction-small-cell carcinoma $(38 \%)$, large-cell carcinoma $(33 \%)$, and adenocarcinoma $(25 \%)$. The importance of looking for evidence of loss of volume on the chest films of patients with bronchogenic carcinoma has been emphasized by Sabour (1964), who found this to be the most frequent single abnormality. His cases were not classified by cell type, however.

Radiographic evidence of a widened mediastinum or mediastinal mass was more characteristic of small-cell carcinoma $(13 \%)$ and large- cell undifferentiated carcinoma (10\%). It was seen in only $2 \%$ of the cases of adenocarcinoma and in $0.8 \%$ of those of squamous-cell carcinoma.

The negative chest films in $3 \%$ of the cases of squamous-cell carcinoma most likely reflect the central location of the tumours in these cases, allowing the lesions to be hidden by the normal hilar shadows. One per cent of the adenocarcinoma patients had negative chest radiographs, but all patients with small-cell or largecell carcinoma had positive radiographs. This study emphasizes the need for detailed work-up, including bronchoscopy of patients with symptoms suggestive of bronchogenic carcinoma, even though the chest radiograph may appear normal.

The views expressed herein are those of the authors, and do not necessarily reflect the views of the Air University, the United States Air Force, or the Department of Defense.

\section{REFERENCES}

Byrd, R. B., Miller, W. E., Carr, D. T., Payne, W. S., and Woolner, L. B. (1968a). The roentgenographic appearance of squamous cell carcinoma of the bronchus. Mayo Clin. Proc., 43, 327.

of large cell carcinoma of the bronchus. Ibid., 43,333 .

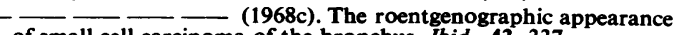
of small cell carcinoma of the bronchus. Ibid., 43, 337 .

Galofré, M., Payne, W. S., Woolner, L. B., Clagett, O. T., and Gage, R. P. (1964). Pathologic classification and surgical treatment of bronchogenic carcinoma. Surg. Gynec. Obstet., 119, 51.

Lehar, T. J., Carr, D. T., Miller, W. E., Payne, W. S., and Woolner, L. B. (1967). Roentgenographic appearance of bronchogenic adenocarcinoma. Amer. Rev. resp. Dis., 96, 245.

Liebow, A. A. (1955). Pathology of carcinoma of the lung as related to the roentgen shadow. Amer. J. Roentgenol., 74, 383.

Lindskog, G. E., Liebow, A. A., and Glenn, W. W. L. (1962). Thoracic and Cardiovascular Surgery with Related Pathology. AppletonCentury-Crofts, New York.

Sabour, M. S. (1964). The radiographic appearance of lung cancer. Brit. J. clin. Pract., 18, 7.

Selby, H. M., Luomanen, R., and Sherman, R. S. (1963). The x-ray appearance of oat-cell cancer of the lung. Radiology, 81, 817 .

Strang, C., and Simpson, J. A. (1953). Carcinomatous abscess of the lung. Thorax, 8, 11 . 